\title{
FORMULASI SEDIAAN SABUN CAIR KOMBINASI EKSTRAK ETANOL DAUN KERSEN (Muntingia calabura L.) DAN DAUN KEMANGI (Ocymum basilicum L.) DAN UJI TERHADAP BAKTERI Staphylococcus aureus
}

\section{FORMULATION OF LIQUID SOAP PREPARATION IN COMBINATION OF ETHANOL EXTRACT FROM KERSEN LEAVES (Muntingia calabura L.) AND BASIL LEAVES (Ocymum basilicum L.) TEST ON Staphylococcus aureus BACTERIA}

\author{
Dwi A. K. Nau'e' ${ }^{1)}$, Paulina V. Y. Yamlean ${ }^{1)}$, Deby A. Mpila ${ }^{1)}$ \\ 1) Program Studi Farmasi FMIPA UNSRAT Manado, 95115 \\ *Dwinaue@gmail.com
}

\begin{abstract}
Kersen leaves (Muntingia Calabura L.) and Basil leaves (Ocymum basilicum L.) are plants that contain flavonoid compounds, saponin and tannin which acts as antibacterial. The aims of this study is formulate liquid soap in combination of ethanol extract of Kersen leaves and basil leaves and to test the antibacterial effectiveness and evaluate the physical preparates of liquid soap in combination of ethanol extract of Kersen leaves and Kemangi leaves. This research uses a laboratorium experimental method. Based on the results of the study showed physical evaluations such as organoleptics which are dark green and dark brown, Soap pH above 8 , measurement height of foam 60-88 mm, calculation of water content was $46 \%$, free alkali content was 0,05-0,06 g/ml, and specific gravity was 1,01-1,09 $\mathrm{g} / \mathrm{ml}$. Liquid soap combination of Kersen and Basil leaves extract has antibacterial effectiveness of average diameter for FI $10 \mathrm{~mm}, \mathrm{~F} 210,33 \mathrm{~mm}, \mathrm{F3} 11 \mathrm{~mm}, \mathrm{~F} 4$ 11,5 mm, and F5 10,67 mm. In conclusion, the combination of Kersen and Basil leaves extract can be formulated into liquid soap, liquid soap preparations in physical evaluation testing had met the standards set by SNI. Liquid soap preparation has antibacterial effectiveness which is included in the strong category.
\end{abstract}

Keywords: Antibacterial, Liquid Soap, Kersen, Basil.

\begin{abstract}
ABSTRAK
Daun Kersen (Muntingia Calabura L.) dan Daun Kemangi (Ocymum basilicum L.) merupakan tanaman yang memiliki kandungan senyawa flavonoid, saponin dan tannin yang bersifat sebagai antibakteri. Penelitian ini bertujuan untuk memformulasikan sabun cair kombinasi ekstrak etanol daun Kersen dan daun Kemangi serta menguji efektivitas antibakteri dan mengevaluasi sediaan fisik dari sabun cair kombinasi ekstrak etanol daun Kersen dan daun Kemangi. Penelitian ini menggunakan metode ekperimental laboratorium. Berdasarkan hasil penelitian menunjukkan evaluasi fisik seperti organoleptik berwarna hijau tua dan cokelat tua, $\mathrm{pH}$ sabun diatas 8 , pengukuran tinggi busa $60-88 \mathrm{~mm}$, perhitungan kadar air yaitu $46 \%$, kadar alkali bebas yaitu 0,05-0,06 g/ml, dan bobot jenis yaitu 1,01-1,09 g/ml. Sediaan sabun cair kombinasi ekstrak daun Kersen dan daun Kemangi memiliki efektifitas antibakteri diameter rata-rata untuk FI $10 \mathrm{~mm}$, F2 10,33 mm, F3 11 mm, F4 11,5 mm, dan F5 10,67 mm. Kesimpulannya kombinasi ekstrak daun Kersen dan daun Kemangi dapat diformulasikan menjadi sabun cair, sediaan sabun cair dalam pengujian evaluasi fisik telah memenuhi standar yang ditetapkan oleh SNI. Sediaan sabun cair memiliki efektifitas antibakteri yang termasuk kategori kuat.
\end{abstract}

Kata Kunci: Antibakteri, Sabun Cair, Kersen, Kemangi. 


\section{PENDAHULUAN}

Indonesia merupakan salah satu Negara yang berada di daerah tropis dan memiliki keanekaragaman hayati yang tinggi. Bahan alam Indonesia telah diketahui memiliki berbagai manfaat dalam bidang kesehatan dan telah diformulasikan dalam berbagai sediaan.

Sesuai dengan Keputusan Menteri Kesehatan No.131/Menkes/SK/II/2004 tentang Sistem Kesehatan Nasional (SKN) yang menyatakan bahwa pengembangan dan peningkatan obat tradisional harus terus dilakukan untuk memperoleh obat yang bermutu tinggi, aman, dan memiliki khasiat yang teruji secara ilmiah baik untuk pengobatan sendiri, masyarakat, maupun digunakan dalam pelayanan kesehatan formal.

Tanaman Kersen (Muntingia calabura L.) mengandung senyawa flavonoid, tanin, saponin yang dapat bersifat sebagai antibakteri Pada penelitian sebelumnya yang dilakukan oleh Lailiyah dan Rahayu (2019), menunjukan bahwa formulasi sediaan sabun cair ekstrak daun Kersen dapat menghambat bakteri Staphylococcus aureus pada konsentrasi 2,5\% dapat menghambat sebesar $16,55 \mathrm{~mm}$, konsentrasi $5 \%$ menghambat sekitar 17,82 mm, dan konsentrasi $7 \%$ dapat menghambat $19,33 \mathrm{~mm}$.

Tanaman Kemangi (Ocimum basilicum L.) merupakan salah satu tanaman obat tradisional yang memiliki banyak manfaat. Penelitian yang telah ada menunjukkan bahwa Kemangi mengandung senyawa yang bersifat insektisida, larvasida, nematisida, antipiretik, fungisida, antimikroba dan antioksidan (Nurcahyanti dan Timotius, 2011). Penelitian tentang formulasi sediaan sabun cair ekstrak daun Kemangi memiliki aktivitas antibakteri terhadap bakteri Staphylococcus aureus pada konsentrasi 3\% memiliki daya hambat $17 \mathrm{~mm}$, konsentrasi $6 \%$ memiliki daya hambat $17,33 \mathrm{~mm}$, konsentrasi $9 \%$ memiliki daya hambat $18,33 \mathrm{~mm}$ (Yamlean dan Bodhi, 2017).

Penyakit infeksi merupakan salah satu masalah dalam bidang kesehatan yang banyak diderita oleh masyarakat Indonesia sejak dahulu yang dari waktu ke waktu terus berkembang. Menurut WHO, sebanyak 25 juta kematian di seluruh dunia pada tahun 2011, sepertiganya disebabkan oleh penyakit infeksi. Penyakit infeksi yang banyak diderita masyarakat disebabkan oleh beberapa bakteri diantaranya Escherichia coli, Staphylococcus aureus, Salmonella thyphi, Pseudomonas aeruginosa, Streptococcus mutans (Dehgani et al., 2012). Staphylococcus aureus merupakan bakteri gram positif anggota family Micrococcaceae berbentuk bulat, bergerombol, seperti susunan buah anggur koloni berwarna abuabu hingga kuning tua. Staphylococcus aureus pada manusia di antaranya ditemukan pada hidung, kulit dan tenggorokan (Brooks et al., 2005). Bisul, jerawat, serta infeksi pada luka merupakan contoh penyakit infeksi yang disebabkan oleh Staphylococcus aureus (Warsa, 1994).

Salah satu cara yang paling sederhana dan paling umum dilakukan untuk menjaga kebersihan kulit ialah dengan mandi menggunakan sabun (Novianti, 2014). Sabun cair adalah sediaan berbentuk cair yang ditujukan untuk membersihkan kulit, dibuat dari bahan dasar sabun yang ditambahkan surfaktan, pengawet, penstabil busa, pewangi dan pewarna yang diperbolehkan, dan dapat digunakan untuk mandi tanpa menimbulkan iritasi pada kulit (SNI, 1996).

Berdasarkan penjelasan tersebut, maka penulis ingin melakukan penelitian mengenai "Formulasi sediaan sabun cair kombinasi ekstrak etanol daun Kersen (Muntingiacalabura L.) dan daun Kemangi (Ocimum basilicum L.) dan uji terhadap bakteri Staphylococcus aureus".

\section{METODOLOGI PENELITIAN}

\section{Waktu dan Tempat Penelitian}

Penelitian dilaksanakan pada bulan November 2019 - Juli 2020 di Laboratorium Farmasi Lanjutan Program Studi Farmasi, Fakultas Matematika dan Ilmu Pengetahuan Alam, Universitas Sam Ratulangi Manado. 


\section{Rancangan Penelitian}

Penelitian ini dilakukan secara eksperimental laboratorium (laboratory experiment) untuk membuat formulasi sediaan sabun cair kombinasi ekstrak daun kersen dan daun Kemangi.

\section{Alat dan Bahan}

Alat

Peralatan yang digunakan yaitu oven, wadah stoples, aluminium foil, kertas saring, blender, $\mathrm{pH}$ meter, alat-alat gelas, timbangan analitik, inkubator, autoklaf, Hot plate magnetic, piknometer, jarum ose, pinset, blender, bejana, batang pengaduk, jangka sorong dan mistar berskala.

\section{Bahan}

Bahan yang digunakan yaitu daun Kemangi, daun Kersen, bakteri Staphylococcus aureus, minyak zaitun, kalium hidroksida $(\mathrm{KOH})$, carboksil metil celulosa (CMC), asam stearat, Aquadest, butyl hidroksi anisol (BHA), fenolftalein, etanol 96\%, nutrien agar, sabun dettol, $\mathrm{NaCl} 0.9 \%, \mathrm{HCl} 0,1 \mathrm{~N}, \mathrm{H}_{2} \mathrm{SO}_{4}$ dan $\mathrm{BaCl}_{2} \cdot 2 \mathrm{H}_{2} \mathrm{O}$.

\section{Prosedur Penelitian}

\section{Pengambilan Sampel}

Sampel tanaman Kersen diambil di Kelurahan Kleak, Kecamatan Malalayang, Kota
Manado dan tanaman Kemangi diambil di Desa Ilomangga, Kecamatan Tabongo, Kota Gorontalo.

\section{Preparasi Sampel}

Sampel tanaman dipreparasi dan daun yang terkumpul masing-masing dicuci bersih dengan air mengalir untuk menghilangkan kotoran. Pengeringan daun dilakukan dengan cara diangin-anginkan dan di oven. Sampel yang telah kering dihaluskan dengan menggunakan blender, setelah itu diayak sehingga mendapatkan serbuk simplisia. Proses ekstraksi dilakukan dengan metode maserasi. Sebanyak 250 g masing-masing serbuk simplisia daun Kersen dan daun Kemangi dimasukkan ke dalam wadah, kemudian dimaserasi dengan pelarut etanol $96 \%$ sebanyak $1250 \mathrm{ml}$. Ditutup dengan alumunium foil dan dibiarkan selama 5 hari sambil sesekali diaduk. Setelah 5 hari, sampel yang dimaserasi tersebut disaring menggunakan kertas saring sehingga menghasilkan filtrat I dan residu I. Residu yang ada kemudian diremaserasi dengan pelarut etanol sebanyak $750 \mathrm{ml}$, ditutup dengan aluminium foil dan dibiarkan selama 3 hari sambil sesekali diaduk. Setelah 3 hari sampel disaring dengan menggunakan kertas saring sehingga menghasilkan filtrat II dan residu II. Filtrat I dan II digabungkan, lalu diuapkan menggunakan oven pada suhu $40^{\circ} \mathrm{C}$ sehingga diperoleh ekstrak kental dari daun Kersen dan daun Kemangi. Setelah itu ekstrak ditimbang dan disimpan dalam wadah tertutup.

\section{Pembuatan Sabun Cair Kombinasi Ekstrak Etanol Daun Kersen dan Daun Kemangi}

Tabel 1. Formula sediaan sabun cair kombinasi ekstrak etanol Daun Kersen (Muntingia calabura L.) dan Daun Kemangi (Ocymum basilicum L.)

\begin{tabular}{ccccccccc}
\hline \multirow{2}{*}{ Bahan } & \multirow{2}{*}{ Fungsi } & \multirow{2}{*}{ Satuan } & \multicolumn{7}{c}{ Konsentrasi } \\
\cline { 4 - 8 } & & & F0 & F1 & F2 & F3 & F4 & F5 \\
\hline $\begin{array}{c}\text { Ekstrak } \\
\text { Etanol }\end{array}$ & & & & & & & \\
Daun & Zat Aktif & $\%$ & & $4: 5$ & $5: 4$ & $4,5: 4,5$ & $6: 3$ & $3: 6$ \\
$\begin{array}{c}\text { Kersen } \\
\text { dan Daun }\end{array}$ & & & & & & & & \\
Kemangi & & & & & & & & \\
\hline Minyak & Asam & $\mathrm{ml}$ & 30 & 30 & 30 & 30 & 30 & 30 \\
\hline
\end{tabular}


PHARMACON- PROGRAM STUDI FARMASI, FMIPA, UNIVERSITAS SAM RATULANGI,

Volume 9 Nomor 3 Agustus 2020

\begin{tabular}{ccccccccc}
\hline Zaitun & Lemak & & & & & & & \\
\hline KOH & Basa & $\mathrm{ml}$ & 16 & 16 & 16 & 16 & 16 & 16 \\
\hline Na-CMC & $\begin{array}{c}\text { Pengisi dan } \\
\text { Pengental }\end{array}$ & $\mathrm{g}$ & 1 & 1 & 1 & 1 & 1 & 1 \\
\hline SLS & Surfaktan & $\mathrm{g}$ & 1 & 1 & 1 & 1 & 1 & 1 \\
\hline $\begin{array}{c}\text { Asam } \\
\text { Stearat }\end{array}$ & Penetral & $\mathrm{g}$ & 0,5 & 0,5 & 0,5 & 0,5 & 0,5 & 0,5 \\
\hline BHA & Antioksidan & $\mathrm{g}$ & 1 & 1 & 1 & 1 & 1 & 1 \\
\hline $\begin{array}{c}\text { Pengaroma } \\
\text { Rose }\end{array}$ & Pengaroma & $\mathrm{ml}$ & 2 & 2 & 2 & 2 & 2 & 2 \\
\hline Aquades & Pelarut & $\mathrm{ml}$ & $\begin{array}{c}\mathrm{ad} \\
100\end{array}$ & $\begin{array}{c}\mathrm{ad} \\
100\end{array}$ & $\begin{array}{c}\mathrm{ad} \\
100\end{array}$ & $\mathrm{ad} 100$ & $\begin{array}{c}\mathrm{ad} \\
100\end{array}$ & $\begin{array}{c}\mathrm{ad} \\
100\end{array}$
\end{tabular}

\section{Pembuatan Sabun Cair Kombinasi Ekstrak Etanol Daun Kersen dan Daun Kemangi}

Semua bahan yang akan digunakan ditimbang terlebih dahulu sesuai dengan takaran yang dianjurkan. Dimasukkan minyak zaitun sebanyak $30 \mathrm{ml}$ ke dalam gelas kimia, kemudian ditambahkan dengan kalium hidroksida $40 \%$ sebanyak $16 \mathrm{ml}$ sedikit demi sedikit sambil terus dipanaskan pada suhu $50^{\circ} \mathrm{C}$ selama kurang lebih 3 jam hingga mendapatkan sabun pasta. Sabun pasta ditambahkan dengan kurang lebih $30 \mathrm{ml}$ aquades, lalu dimasukkan natrium karboksil metil selulosa yang telah dikembangkan dalam aquades panas, diaduk hingga homogen selama kurang lebih 10 menit. Kemudian ditambahkan asam stearat, diaduk hingga homogen selama kurang lebih 10 menit. Ditambahkan sodium laurel sulfat, diiaduk hingga homogen selama kurang lebih 10 menit. Ditambahkan butyl hidroksi anisol, lalu diaduk hingga homogen. Dimasukkan kombinasi ekstrak daun Kersen dan daun Kemangi, diaduk hingga homogen selama kurang lebih 10 menit. Sabun cair ditambahkan dengan aquades hingga volumenya $100 \mathrm{ml}$, dimasukkan ke dalam wadah bersih yang telah disiapkan. Pembuatan sabun cair kombinasi ekstrak daun Kersen dan daun Kemangi disesuaikan dengan masing-masing konsentrasi. Setelah itu dilakukan uji organoleptik, $\mathrm{pH}$, tinggi busa, kadar air, bobot jenis dan kadar alkali bebas.

\section{HASIL DAN PEMBAHASAN}

Formulasi sediaan sabun cair dibuat dengan menggunakan zat aktif yaitu kombinasi ekstrak daun Kersen dan daun Kemangi. Sediaan sabun cair ini diformulasikan dengan basis sabun yaitu minyak zaitun sebagai basis minyak dan $\mathrm{KOH}$ sebagai basa untuk membentuk sabun pasta. Sabun cair dibuat melalui reaksi saponifikasi dari minyak dan lemak dengan KOH (Mitzui, 1997). Bahan yang digunakan sebagai pengetal dan mengisi massa dari sabun yaitu CMC, selanjutnya penambahan asam stearat sebagai penetral, bertujuan agar basa yang tidak berikatan dengan minyak atau basa yang bersifat bebas dapat ditarik dan berikatan dengan zat penetral (Dimpudus et al., 2017). Selanjutnya penambahan SLS sebagai surfaktan yang menghasilkan busa pada sabun cair. Kemudian antioksidan yang digunakan pada sabun cair ini BHA dan digunakan pengeroma seperti pengaroma rose yang dapat membuat keharuman pada sabun cair.

Tabel 2. Hasil uji organoleptik

\begin{tabular}{cccc}
\hline Sediaan & Bentuk & Bau & Warna \\
\hline F0 & Cair & Khas & Putih \\
\hline F1 & Cair & Khas & Hijau Tua \\
\hline F2 & Cair & Khas & $\begin{array}{c}\text { Cokelat } \\
\text { Tua }\end{array}$ \\
\hline F3 & Cair & Khas & $\begin{array}{c}\text { Cokelat } \\
\text { Tua }\end{array}$ \\
\hline F4 & Cair & Khas & $\begin{array}{c}\text { Cokelat } \\
\text { Tua }\end{array}$ \\
\hline F5 & Cair & Khas & Hijau Tua \\
\hline
\end{tabular}


Uji organoleptik yang bertujuan untuk melihat tampilan fisik dari sediaan sabun cair kombinasi ekstrak daun Kersen dan daun Kemangi yang meliputi bentuk, warna dan bau. Bentuk yang dihasilkan dari sabun cair ini yaitu cair, bau yang dihasilkan memiliki bau khas dari ekstrak, walaupun sudah ditambahkan pengaroma rose. Sabun cair yang dihasilkan berwarna cokelat tua dan hijau tua, hal ini dikarenakan ekstrak dari daun Kersen yang berwarna cokelat tua dan untuk warna dari ekstrak daun Kemangi berwarna hijau tua. Jika dikombinasikan keduanya maka salah satu yang dominan akan mengikuti warna dari ekstrak tersebut. Syarat SNI yaitu sediaan sabun cair masih berbentuk homogen dan tidak terjadi perubahan bentuk menjadi 2 fase serta memiliki bau yang khas, bau khas tersebut merupakan bau dari ekstrak tanaman yang digunakan yaitu ekstrak daun Kersen dan daun Kemangi. Berdasarkan hasil yang diperoleh, hasil uji organoleptik sabun cair yang dihasilkan memenuhi syarat SNI.

Tabel 3. Hasil uji pH

\begin{tabular}{cccccc}
\hline \multicolumn{7}{c}{ Hasil pengukuran pH } \\
\hline Perlak & Perlak & Perlak & Rata- \\
uan 1 & uan 2 & uan 3 & Ketera \\
rata & ngan \\
\hline F0 & 8,47 & 8,96 & 8,28 & 8,57 & $\begin{array}{c}\text { Memenuhi } \\
\text { syarat }\end{array}$ \\
\hline F1 & 8,35 & 8,68 & 8,54 & 8,49 & $\begin{array}{c}\text { Memenu } \\
\text { hi syarat }\end{array}$ \\
\hline F2 & 7,69 & 8,68 & 8,48 & 8,28 & $\begin{array}{c}\text { Memenu } \\
\text { hi syarat }\end{array}$ \\
\hline F3 & 8,05 & 8,81 & 7,93 & 8,26 & $\begin{array}{c}\text { Memenu } \\
\text { hi syarat }\end{array}$ \\
\hline F4 & 8,53 & 8,86 & 8,35 & 8,58 & $\begin{array}{c}\text { Memenu } \\
\text { hi syarat }\end{array}$ \\
\hline F5 & 8,89 & 8,18 & 8,6 & 8,56 & $\begin{array}{c}\text { Memenu } \\
\text { hi syarat }\end{array}$ \\
\hline
\end{tabular}

Pengujian $\mathrm{pH}$ bertujuan untuk melihat $\mathrm{pH}$ pada sediaan sabun cair kombinasi ekstrak daun Kersen dan daun Kemangi. Pengujian $\mathrm{pH}$ diperlukan karena sabun cair akan langsung bersentuhan dengan kulit, Syarat SNI untuk uji $\mathrm{pH}$ yaitu antara 8,0-8,6. Jika $\mathrm{pH}$ yang dihasilkan tidak sesuai syarat yang ditetapkan oleh SNI, maka dapat mengakibatkan masalah pada kulit. Kulit manusia memiliki kapasitas ketahanan dan dapat dengan cepat beradaptasi dengan produk yang mempunyai pH antara 8,0-10,8 (Frost dan Horowitz, 1982). Berdasarkan hasil uji $\mathrm{pH}$ yang diperoleh menunjukan sediaan sabun cair kombinasi ekstrak daun Kersen dan daun Kemangi memenuhi syarat SNI yaitu memiliki pH diantara 8-11.

Tabel 4. Hasil uji tinggi busa

\begin{tabular}{cccccc}
\hline \multicolumn{6}{c}{ Hasil pengukuran Tinggi } \\
Busa (mm)
\end{tabular}

Pengujian berikut yaitu uji tinggi busa pada sabun cair. Syarat dari SNI, tinggi busa dari sabun cair harus berada pada diantara 13-220 mm. Berdasarkan hasil pengujian dari tinggi busa sabun cair kombinasi ekstrak daun Kersen dan daun Kemangi memiliki tinggi busa sekitar $60-88 \mathrm{~mm}$, yang berarti hasil tinggi busa yang dihasilkan sesuai dengan syarat dari SNI. Reaksi saponifikasi yaitu reaksi pembentukan sabun yang membutuhkan adanya basa dan minyak, reaksi saponifikasi ditandai dengan terbentuknya busa (Susanti dan Guterres, 2018). Selain proses saponifikasi yang dapat menghasilkan busa, SLS juga merupakan bahan yang dapat menghasilkan busa pada sabun cair. Salah satu daya tarik dari sabun cair adalah kandungan busanya. Fungsi busa dalam sabun untuk mencegah redeposisi artinya agar partikel kotoran yang sudah terlarut di air oleh sabun tidak terjatuh atau mengendap lagi, sehingga 
kotoran dapat dibuang bersama air sabunnya (Sahambangung et al., 2019)

Tabel 5. Hasil uji kadar air

\begin{tabular}{cccccc}
\hline \multicolumn{7}{c}{ Hasil perhitungan Kadar } \\
Air (\%) \\
\hline & $\begin{array}{c}\text { Perlak } \\
\text { uan 1 }\end{array}$ & $\begin{array}{c}\text { Perlak } \\
\text { uan 2 }\end{array}$ & $\begin{array}{c}\text { Perlak } \\
\text { uan 3 }\end{array}$ & $\begin{array}{c}\text { Rata- } \\
\text { rata }\end{array}$ & $\begin{array}{c}\text { Ketera } \\
\text { ngan }\end{array}$ \\
\hline F0 & 62,65 & 64,91 & 65,11 & 64,23 & $\begin{array}{c}\text { Tidak } \\
\text { Memenu } \\
\text { hi syarat }\end{array}$ \\
\hline F1 & 43,07 & 45,96 & 50,82 & 46,62 & $\begin{array}{c}\text { Memenu } \\
\text { hi syarat }\end{array}$ \\
\hline F2 & 46,29 & 47,89 & 44,79 & 46,32 & $\begin{array}{c}\text { Memenu } \\
\text { hi syarat }\end{array}$ \\
\hline F3 & 44,50 & 46,43 & 47,53 & 46,15 & $\begin{array}{c}\text { Memenu } \\
\text { hi syarat }\end{array}$ \\
\hline F4 & 44,19 & 47,26 & 48,03 & 46,49 & $\begin{array}{c}\text { Memenu } \\
\text { hi syarat }\end{array}$ \\
\hline F5 & 47,60 & 49,63 & 42,58 & 46,60 & $\begin{array}{c}\text { Memenu } \\
\text { hi syarat }\end{array}$ \\
\hline
\end{tabular}

Berikutnya dilakukan pengujian kadar air dari sabun cair yang bertujuan untuk mengetahui presentase kandungan air yang terdapat dalam sedian sabun cair. Syarat yang telah ditetapkan oleh SNI yaitu maksimal 60\%. Berdasarkan hasil uji kadar air yang didapatkan,sabun cair kombinasi ekstrak daun Kersen dan daun Kemangi menunjukkan bahwa semua konsentrasi memenuhi syarat yang ditetapkan oleh SNI, kecuali pada basis sabun memiliki kadar air yang lebih dari $60 \%$ disebabkan karena ada beberapa bahan yang bersifat higroskopis seperti SLS (Sodium Lauryl Sulfate) dan Na-CMC (Natrium Carboxy Methyl Cellulose), semakin tinggi konsentrasi ekstrak maka semakin kecil presentase kadar air yang didapatkan (Dimpudus et al., 2017). Hal ini yang membuat basis sabun cair tidak memenuhi syarat yang ditetapkan oleh SNI.

Tabel 6. Hasil uji kadar alkali bebas

\section{Hasil perhitungan Bobot} Jenis $(\mathrm{g} / \mathrm{ml})$

\begin{tabular}{cccccc}
\hline & $\begin{array}{c}\text { Perlak } \\
\text { uan 1 }\end{array}$ & $\begin{array}{c}\text { Perlak } \\
\text { uan 2 }\end{array}$ & $\begin{array}{c}\text { Perlak } \\
\text { uan 3 }\end{array}$ & $\begin{array}{c}\text { Rata- } \\
\text { rata }\end{array}$ & $\begin{array}{c}\text { Ketera } \\
\text { ngan }\end{array}$ \\
\hline F0 & 0,047 & 0,056 & $\begin{array}{c}0,04 \\
7\end{array}$ & 0,05 & $\begin{array}{c}\text { Memenuhi } \\
\text { syarat }\end{array}$
\end{tabular}

\begin{tabular}{|c|c|c|c|c|c|}
\hline $\mathrm{F} 1$ & 0,038 & 0,047 & $\begin{array}{c}0,06 \\
6\end{array}$ & 0,05 & $\begin{array}{l}\text { Memenu } \\
\text { hi syarat }\end{array}$ \\
\hline F2 & 0,047 & 0,075 & $\begin{array}{c}0,06 \\
6\end{array}$ & $\begin{array}{c}0,06 \\
3\end{array}$ & $\begin{array}{l}\text { Memenu } \\
\text { hi syarat }\end{array}$ \\
\hline F3 & 0,056 & 0,065 & $\begin{array}{c}0,07 \\
5\end{array}$ & $\begin{array}{c}0,06 \\
5\end{array}$ & $\begin{array}{l}\text { Memenu } \\
\text { hi syarat }\end{array}$ \\
\hline F4 & 0,047 & 0,056 & $\begin{array}{c}0,07 \\
5\end{array}$ & $\begin{array}{c}0,05 \\
9\end{array}$ & $\begin{array}{l}\text { Memenu } \\
\text { hi syarat }\end{array}$ \\
\hline F5 & 0,066 & 0,066 & $\begin{array}{c}0,05 \\
6\end{array}$ & $\begin{array}{c}0,06 \\
2\end{array}$ & $\begin{array}{l}\text { Memenu } \\
\text { hi syarat }\end{array}$ \\
\hline
\end{tabular}

Uji alkali bebas pada sabun cair bertujuan untuk melihat jumlah alkali atau basa yang tidak berikatan dengan asam lemak atau minyak zaitun. Kadar alkali bebas yang ditetapkan oleh SNI maksimal $0,1 \%$. Hasil yang diperoleh berdasarkan pengujian alkali bebas pada sabun cair berada kurang dari $0,1 \%$ sehingga kadar alkali dari masing-masing formulasi memenuhi syarat SNI. Hal ini disebabkan karena pada saat pembuatan sabun cair dilakukan pemanasan yang cukup lama disertai dengan pengadukan sehingga sabun telah menjadi pasta, karena kalium hidroksida yang merupakan salah satu pembentuk basis sabun sudah beraksi dengan asam lemak atau minyak zaitun tersebut (Korompis et al., 2020).

Tabel 7. Hasil uji bobot jenis

\begin{tabular}{cccccc}
\hline \multicolumn{7}{c}{ Hasil perhitungan } \\
Bobot Jenis $(\mathbf{g} / \mathrm{ml})$
\end{tabular}


Uji bobot jenis dilakukan untuk mengetahui bobot jenis dari sabun cair. Bobot jenis berdasarkan Standar Nasional Indonesia yaitu $1,01-1,1 \mathrm{~g} / \mathrm{ml}$. Nilai dari bobot jenis sabun cair ini dipengaruhi oleh bahan penyusunnya dan sifat fisiknya, Berdasarkan hasil pengujian bobot jenis, didapatkan nilai berada diantara 1,01-1,09 $\mathrm{g} / \mathrm{ml}$, yang berarti sediaan sabun cair yang diformulasikan telah memenuhi standar yang ditetapkan oleh SNI. Dengan demikian, bobot jenis sabun cair pada penelitian ini dapat diharapkan dapat mudah dibersihkan dengan air mengalir karena memiliki bobot jenis yang mendekati bobot jenis air (Sari dan Ferdinan, 2017).

Tabel 8. Hasil pengujian antibakteri

\begin{tabular}{cccccc}
\hline \multicolumn{5}{c}{ Hasil pengukuran diameter zona hambat $(\mathbf{m m})$} \\
\hline $\mathrm{K}(-)$ & Perlakuan 1 & Perlakuan 2 & Perlakuan 3 & Rata-rata & Keterangan \\
\hline $\mathrm{K}(+)$ & 1 & 0,5 & 1 & 0,83 & Lemah \\
\hline $\mathrm{F} 1$ & 15 & 15 & 15 & 15 & Kuat \\
\hline $\mathrm{F} 2$ & 10,5 & 10 & 9,5 & 10 & Kuat \\
\hline F3 & 10,5 & 10 & 10,5 & 10,33 & Kuat \\
\hline F4 & 11 & 11 & 11 & 11 & Kuat \\
\hline F5 & 11,5 & 11,5 & 11,5 & 11,5 & Kuat \\
\hline
\end{tabular}

Pengujian antibakteri sabun cair kombinasi ekstrak daun Kersen dan daun Kemangi bertujuan untuk mengetahui sediaan sabun cair yang diformulasikan bisa menghambat bakteri Staphylococcus aureus. Pengujian antibakteri dilakukan 3 kali pengulangan pada masing-masing formulasi, hal ini agar hasil yang didapatkan lebih akurat. Pada pengujian antibakteri menggunakan media nutrient agar. Hasil dari pengujian antibakteri dari sediaan sabun cair ini memiliki zona hambat berkisar dari $10 \mathrm{~mm}$ sampai $11,5 \mathrm{~mm}$. Menurut Davis dan Stout (1971), dikategorikan berdasarkan diameter zona hambat yang terbentuk yaitu diameter zona hambat $5 \mathrm{~mm}$ atau kurang dikategorikan lemah, zona hambat 5-10 mm dikategorikan sedang, zona hambat 10-20 mm dikategorikan kuat dan zona hambat $20 \mathrm{~mm}$ atau lebih dikategorikan sangat kuat. Dari hasil yang didapatkan dapat dikatakan bahwa sediaan sabun cair ekstrak daun Kersen dan daun Kemangi dengan memvariasikan konsentrasinya memperlihatkan daya hambat yang kuat terhadap bakteri Staphylococcus aureus, formulasi 1 dengan perbandingan $4 \%: 5 \%$ memiliki daya hambat sebesar $10 \mathrm{~mm}$, formulasi 2 perbandingan 5\%:4\% memiliki daya hambat sebesar 10,33 mm, formulasi 3 perbandingan 4,5\%:4,5\% memiliki daya hambat sebesar $11 \mathrm{~mm}$, formulasi 4 dengan perbandingan 6\%:3\% memiliki daya hambat terbesar dan formulasi 5 perbandingan 3\%:6\% memiliki daya hambat sebesar $10,67 \mathrm{~mm}$ terhadap bakteri Staphylococcus aureus. Hal yang menyebabkan formulasi 4 memiliki daya hambat terbesar dikarenakan konsentrasi ekstrak daun kersen pada formulasi 4 lebih tinggi dibandingkan dengan formulasi yang lain. Lebih besarnya daya hambat yang terbentuk dari ekstrak daun kersen dibandingkan dengan daun kemangi dapat dipengaruhi oleh mutu ekstrak dari daun. Mutu ekstrak dipengaruhi dua faktor utama yaitu faktor biologi dan faktor kimia. Faktor biologi meliputi spesies tanaman, lokasi tanaman asal, waktu pemanenan, penyimpanan bahan baku, umur serta bagian tanaman yang digunakan. Lokasi tanaman dipengaruhi oleh lingkungan seperti tanah, atmosfir, cuaca, temperatur, cahaya, air, senyawa organik dan anorganik. Waktu panen juga mempengaruhi kandungan zat aktif daun, dimana kandungan zat aktif mencapai jumlah optimal pada saat tanaman akan berbunga (Mishra et al., 2007). Faktor kedua adalah faktor kimia antara lain faktor eksternal dan faktor internal. Faktor eksternal yang mempengaruhi meliputi ukuran bahan, penyaring yang digunakan dalam ekstraksi, kandungan logam berat, pestisida pada tanaman dan metode ekstraksi yang digunakan (Hermawan, 2007). Dalam 
penelitian ini kemungkinan ukuran dari bahan atau simplisia sebelum dilakukan ekstraksi, simplisia dari daun kersen lebih halus dibandingkan dengan daun kemangi sehingga kandungan yang diambil lebih sedikit dibandingkan dengan daun kersen. Pada formulasi 5 dengan konsentrasi 3\%:6\% memiliki daya hambat lebih besar dari pada formulasi 2 dengan konsentrasi 5\%:4\% bisa disebabkan pengaruh dari viskositas sediaan sabun cair, formulasi 5 lebih cair dibandingkan dengan formulasi 2 yang dimana semakin besar viskositas sediaan maka semakin besar pula tahanannya, yang membuat kecepatan difusi senyawa antibakteri semakin lama dan membuat daya hambat yang dihasilkan semakin kecil (Sinko, 2011). Perbedaan viskositas juga bisa mempengaruhi daya hambat bakteri yang dihasilkan oleh tiap-tiap formulasi berbeda.

Pada pengujian antibakteri juga menggunakan kontrol negatif dan positif sebagai pembanding, untuk daya hambat dari setiap formulasi ini lebih rendah dari kontrol positif, kontrol positif yang digunakan yaitu dettol yang mengandung bahan aktif chloroxylenol. Selain itu kontrol negatif yang digunakan yaitu basis sabun cair yang ternyata memiliki zona hambat bakteri Staphylococcus aureus, dengan diameter zona hambatnya rata-rata $0,83 \mathrm{~mm}$ yang dikategorikan lemah. Penyebab dari basis sabun ini memiliki daya hambat yaitu karena dalam memformulasikan sabun cair menggunakan bahan minyak zaitun sebagai asam lemak, minyak zaitun ini memiliki senyawa fenolik dan vitamin E. Menurut Guenther (1987), senyawa fenolik aktif bersifat sebagai antimikroorganisme dengan mekanisme membentuk kompleks dengan protein sel sehingga menghambat kerja enzim pada mikroorganisme. Hal ini yang membuat basis sabun cair memiliki zona hambat terhadap bakteri walau zona hambatnya masih dikategorikan lemah.

\section{KESIMPULAN}

Berdasarkan hasil penelitian maka dapat disimpulkan kombinasi ekstrak daun Kersen dan daun Kemangi dapat diformulasikan menjadi sabun cair, sediaan sabun cair dalam pengujian evaluasi fisik telah memenuhi standar yang ditetapkan oleh SNI. Sediaan sabun cair memiliki efektifitas antibakteri yang termasuk kategori kuat.

\section{SARAN}

Disarankan kepada peneliti selanjutnya untuk melakukan uji evaluasi fisik yang lain seperti uji viskositas, uji asam lemak dan uji iritasi.

\section{DAFTAR PUSTAKA}

Brooks, G. F., J. S. Butel dan S. A. Morse. 2005. Medical Microbiology. Mc Graw Hill, New York.

Davis, W. W. dan Stout, T. R. 1971. Disc Plate Methods of Microbiological Antibiotic Assay. Microbiology. 22(4): 659-665.

Dimpudus, S., Yamlean, P. dan Yudistira, A. 2017. Formulasi Sediaan Sabun Cair Antiseptik Ekstrak Etanol Bunga Pacar Air (Impantiens balsamina L.) dan Uji Efektivitasnya Terhadap Bakteri Staphylococcus aureus Secara In Vitro. Jurnal Pharmacon. 6(3): 208-215.

Departemen Kesehatan RI, Materi Sosialisasi SKN dan Kebijakan Depkes Tingkat Regional di Makassar 30 - 31 Agustus 2004.

Dehghani, F., Heshmatpour, A., Panjeshahin, M.R. and Khozani, T.T. 2012. Toxic effects of water/ alcoholic extract of Syzygium aromticum on sperm quality, sex hormones hormones and reproductive tissues in male mouse. IUFS J Biol 71(2): 95-102.

Frost, P., dan Horowitz, S. 1982. Principals of Cosmetics for the Dermatologist. C.V Mosby Co. England.

Guenther, E. 1987. Minyak Atsiri Jilid I. Penerbit Universitas Indonesia, Jakarta.

Hermawan, A. 2007. Pengaruh Ekstrak Daun Sirih (Piper betle L.) terhadap pertumbuhan Staphylococcus aureus dan Escherichia coli dengan metode Difusi Disk. Fakultas Kedokteran Sciences. (54) 370-381

Korompis, F., Yamlean, P., dan Lolo, W. 2020. Formulasi dan Uji Efektivitas Antibakteri Sediaan Sabun Cair Ekstrak Etanol Daun Kersen (Muntingia Calabura L.) Terhadap 
Bakteri Staphlococcous epidermidis. Jurnal Pharmacon. 9(1): 30-37.

Lailiyah, M. dan Rahayu, D. 2019. Formulasi dan Uji Aktivitas Antibakteri Sabun Cair Dari Ekstrak Daun Kersen (Muntingia Calabura L.) Terhadap bakteri staphylococcus aureus. Jurnal Hestech, 2(1): 15-24.

Mishra, S. K., Sangwan, N. S., Sangwan, R. S. 2007. Andrographis paniculata (kalmegh): a review. Pharmacognosy Reviews. (1) 28377.

Sari, R., dan Ferdinan, A. 2017. Pengujian Aktivitas Antibakteri Sabun Cair dari Ekstrak Kulit Daun Lidah Buaya. Pharm Sci Re. 4(3): 111-120.
Sahambangung, M. A., Datu, O. S., Tiwow, G. A. R., dan Potolangi, N, O. 2019. Formulasi Sediaan Sabun Antiseptik Ekstrak Daun Pepaya Carica papaya. Jurnal Biofarmasetikal Tropis, 2(1): 43-51.

Susanti, M. M dan Guterres, A. D. A. 2019. Pengaruh Penambahan Kalium Hidroksida (KOH) Terhadap Mutu Sabun Lunak Berbahan Dasar Minyak Goreng Bekas. Jurnal Medsains, 4(1): 25-33.

Sinko, P. J. 2011. Martin Farmasi Fisila Dan Ilmu Farmasetika Edisi 5. UI Press, Jakarta.

Warsa, U. C. 1994. Staphylococcus dalam Buku Ajar Mikrobiologi kedokteran. Binarupa Aksara, Jakarta. 